\title{
COMMUNITY BASED WARNING AND EVACUATION SYSTEM AGAINST DEBRIS FLOW IN THE UPPER JENEBERANG RIVER, GOWA, SOUTH SULAWESI
}

\author{
Sutikno Hardjosuwarno \\ Experimantal Station for Sabo, Research Center for Water Resources Development, \\ Agency for Research and Development of Public Works, \\ Ministry of Public Works of the Republic of Indonesia, \\ Sopalan, Maguwoharjo, Depok, Sleman, 55282 Yogyakarta-INDONESIA \\ Phone: 0274-886350, hp: 08122941031, \\ E-mail: sutiknohs@hotmail.com
}

\begin{abstract}
Gigantic collapse of the Caldera wall of Mt. Bawakaraeng $(2,830 \mathrm{~m})$ in March 2004 had supplied the sediment volume of 230 millions to the most upper stream of Jeneberang River, which flowed down to the lower reach in the form of debris flow which is triggered by rainfall. The purpose of the research is to provide a system which is able to forecast the occurrence of debris flow, to identify the weak points along the river course, to identify the hazard areas and how to inform effectively and efficiently the warning messages to the inhabitants in the dangerous area by using the existing modern equipment combined with the traditional one. The standard rainfall which is used to judge the occurrence of debris flow was established by Yano method. It is based on the historical data of rainfall that trigger and not trigger to the occurrence of debris flow which is widely used in Japan so far. The hazard area was estimated by Two-Dimensional Simulation Model for debris flow, the debris flow arrival time at each point in the river were estimated by dividing their distance from reference point by debris flow velocity, where the check dam no. 7-1 in Manimbahoi was designated as reference point. The existing evacuation routes were checked by field survey, the strength and coverage of sound for kentongan and manual siren were examined using sound pressure level at the location of the existing monitoring post and the effectiveness of warning and evacuation were evaluated by comparing the warning and evacuation time against the debris flow arrival time. It was resulted that debris flow occurrence was triggered by short duration of high rainfall intensity, long duration of low rainfall intensity and the outbreak of natural dam which is formed by land slide or bank collapses. The hazard area of upper Jeneberang River are mostly located on the river terraces where the local inhabitants earn their living through cultivating the river terraces as paddy fields, dry field and sand mining. It was also resulted that at the elevation of $700 \mathrm{~m}$ to the upper stream, the arrival time of debris flow is too short $(<3$ minutes), it means that there is no time to evacuate when debris flow occurs. There are enough time to evacuate along the reaches between $700 \mathrm{~m}$ to $390 \mathrm{~m}$ and more time to evacuate along the downstream of $390 \mathrm{~m}$ river bed elevation due to the longer arrival time of debris flow. The existing community based warning system against debris flow uses radio transceiver to communicate between post and uses kentongan and sirens to propagate the warning message to inhabitants. Based on the sound test conducted in Jeneberang river, the manual siren has a coverage of $160 \mathrm{~m}$ to $600 \mathrm{~m}$ and it can be used in the warning system, being co-existence with the kentongan which has been used for a long time. In order to keep the community based warning system well functioned, it is recommended to synergize between the Local Government of Gowa Regency and the other stake holders with the inhabitants along Jeneberang River and the Sabo Community of Jeneberang in the operation and maintenance of the system.
\end{abstract}

Keywords: collapse, rainfall, debris flow, warning system, evacuation disaster prone area,.

\section{INTRODUCTION}

Jeneberang river is situated in the Regency of Gowa, Province of South
Sulawesi. It is originated from Mt. Bawakaraeng at an elevation of $2,833 \mathrm{~m}$ above mean sea level, it has $75 \mathrm{~km}$ length, drains $727 \mathrm{~km} 2$ and ends in the Makassar 
Bay. The gigantic collapse of the caldera wall of Mt. Bawakaraeng in March 24, 2004 has produced a 230 millions of sediment in the upper stream of the river and has caused debris flows that buried a wide land of paddy field or plantation along the river terraces and threatened the inhabitants who are working on. It will also shorten the service life of Bili-Bili multipurpose reservoir located $35 \mathrm{~km}$ downstream of the caldera. Following the gigantic collapse, the smaller collapses have occurred many times and it was predicted that there will be a lot of collapses in the future due to the existence of 32 points of active cracks on the back of the caldera.

The inhabitants that earn their living from farming mostly work on the river ter- races to cultivate their paddy field, dry field or plantation, but their houses are mostly located in the higher elevation and mostly safe from debris flow hazard except in some places in Bulo, Tanete and Limbua, the elevation of river bed is higher than the village. In order to protect the inhabitants from debris flow out break, it is quite necessary to develop the community based warning and evacuation system. In order to make the inhabitants accustomed to provide their own effort to evacuate from the hazard, their ability to identify the natural phenomena should be improved to make them able to decide when, where and how they should evacuate.

Besides improving their ability to build their own self confidence to estab-

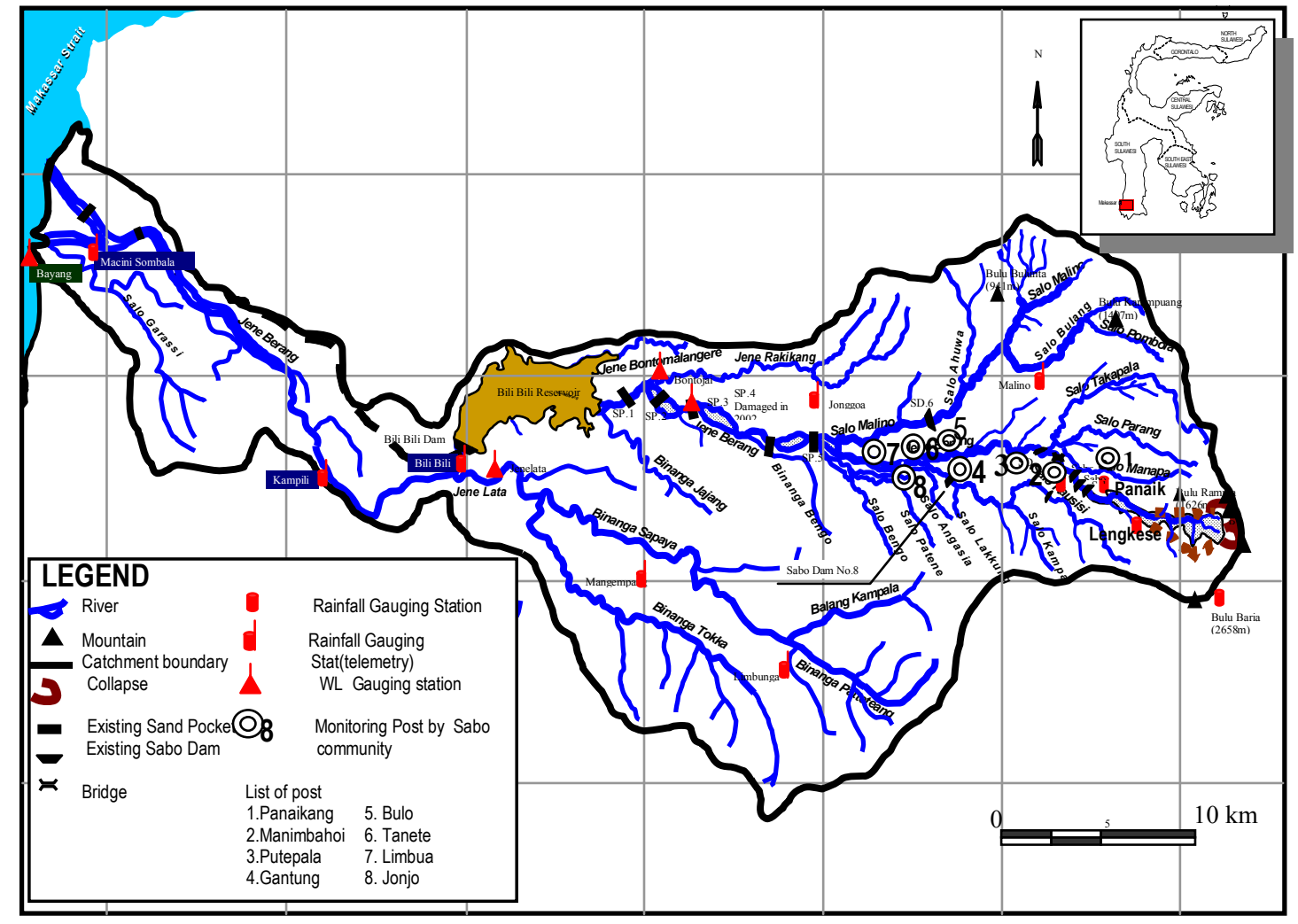

Source: CTIE, et al, 2006, Report on Urgent Survey for Consulting Engineering Services of Bawakaraeng Urgent Sediment Control Project, The Most Urgent Components, The Government of the Republic of Indonesia, Ministry of Public Works, Directorate General of Water Resources.

Figure 1. Map of Jeneberang River Basin 
lish a measure, it also needs to give technical support that consists of study on debris flow forecasting, warning and evacuation system. The study to identify the hazard prone areas and the arrival time of debris flow to reach the area are also needed. Understanding these matters will enable the inhabitants to decide when and where they have to evacuate. The purpose of the research is to establish a system which is able to forecast the occurrence of debris flow, to identify the weak points along the river course, to identify the hazard areas and how to convey effectively and efficiently the warning messages to the inhabitants in the hazard area by using the existing modern equipment combined with the traditional one.

\section{METHOD}

Yano method was applied to establish a standard rainfall for debris flow (Yano, et al, 1985). It will be used to make a threshold of rainfall which may trigger debris flow. The method needs a long record of rainfall and the occurrence of debris flow. The only long data record of rainfall in the upper Jeneberang river is Malino station, the other existing stations are Panaikang, Lengkese and Majannang have too short rainfall data record. Due to significant difference between rainfall in Malino and Panaikang where the daily rainfall in Panaikang is 1.8 times of Malino station (CTIE, et. al, 2006), it can not be used for the analysis of standard rainfall for debris flow occurrence. For the analysis of standard rainfall for debris flow occurrence, Lengkese station $(1,000 \mathrm{~m})$ that is closest to the caldera was used, even the record length is only 28 months with a hope that never ending update of standard rainfall can be done using new data.
The selected data used in the analysis are serial rainfall that trigger or not trigger to the mudflow occurrence, preceded and followed by 24 hours without rain. Variables in the analysis are (1) all serial rainfall that do not trigger debris flow having cumulative rainfall e" $80 \mathrm{~mm}$ or rainfall intensity e" $20 \mathrm{~mm}$; (2) serial rainfall that trigger the large scale of debris flow; (3) antecedent precipitation during 14 days prior to the start of the series as a variable of saturation, calculated by Equation (1) and Equation (2);;(4) cumulative rainfall at the maximum intensity; (5) maximum rainfall intensity; (6) cumulative rainfall at the occurrence of debris flow. The sum of variable (3) and (4) is designated as working rainfall for non occurrence and the sum of variable (3) and (6) is designated as working rainfall of occurrence that effects the occurrence of debris flow. The standard rainfall for debris flow can be established tentatively y drawing a line separating the plotted points between occurrence working rainfall against rainfall intensity at the occurrence of debris flow, and non occurrence working rainfall against maximum rainfall intensity.

$$
R w a=\sum_{t=1}^{t=14} \alpha t . d t
$$$$
\alpha t=0.5^{1 / T}
$$

In which, Rwa is antecedent precipitation, $d t$ is daily rainfall at $t$ days before debris flow occurrence, $a=$ deduction coefficient and $T$ is half life period (Yano, et al, 1985).

The hazard area from Manimbahoi (el. $800 \mathrm{~m}$ ) to the confluence point of Malino river with Jeneberang River was estimated by two-dimensional simulation model for debris flow. The simulation re- 
sult is than compared with the historical data of debris flow for calibration. The base map of the hazard debris area is the topographical map (RBI) at the scale of 1:50,000, produced in 2005 by BAKOSURTANAL. The debris flow arrival time at each point in the river were estimated by dividing their distance from reference point. The check dam no. 7-1 in Manimbahoi has been designated as reference point. The existing evacuation routes were examined by field survey; the strength and coverage of sound for kentongan and manual siren were examined using sound pressure level at the location of the existing monitoring posts. The effectiveness of warning and evacuation were evaluated by comparing the warning and evacuation time against the debris flow arrival time.

The performance of warning and evacuation system can be evaluated by comparing the arrival time of debris flow at a point and total time needed for propagating warning messages and evacuation. The arrival time of debris flow was estimated by Manning Formula as shown on Equation (3), (4) and (5).

$$
\begin{aligned}
& t=L / v \ldots \ldots . . . \\
& v=\frac{1}{n} h^{2 / 3} i^{1 / 2} \ldots \\
& h=\left[\frac{q p \cdot n}{B \cdot i^{1 / 2}}\right]^{3 / 5}
\end{aligned}
$$

in which, $t$ is arrival time of debris flow, $L$ is distance of the respective points to the reference point, $v$ is debris flow velocity in $\mathrm{m} 3 / \mathrm{s}, q$ is discharge per unit width in $\mathrm{m} 2 /$ $\mathrm{s}, \mathrm{B}$ is channel width in $\mathrm{m}$ ', $\mathrm{I}$ is the slope of river bed an $\mathrm{n}$ is Manning roughness coefficient. The peak discharge of debris flow of $1000 \mathrm{~m}^{3} / \mathrm{s}$ at the check dam no 7-1 re- corded in February 2007 (Hazama-Brantas, 2007) was used as a reference. Using the peak discharge at reference point, channel width and the slope of river bed at respective reaches, the flow depth and velocity can be calculated. The evacuation can only be done if the total time of conveying warning messages and evacuation time is smaller than the arrival time of debris flow. In the case that the total time is greater than the arrival time of debris flow, there will be no chance to evacuate (Sutikno Hardjosuwarno, 2005).

\section{RESULT AND DISCUSSION}

\section{Standard Rainfall for Debris Flow Oc- currence.}

Generally the occurrence of debris flow is governed by rainfall concentrated on the pyroclastic deposit or unstable sediment. In the active volcanoes the pyroclastic material is originated from eruption. it consists of ejected material or lava avalanche. In the non volcanic area however, the pyroclastic material comes from landslide or collapse. The existence of unstable pyroclastic material on a slope of greater than $5.2 \%$ and is triggered by heavy rainfall concentrated on the area may cause debris flow. The material source of debris flow in Jeneberang River is mainly originated from the collapsed material of caldera wall occurred in March 2004, the others comes from bank collapse in the upstream of Jeneberang river. In order to forecast the occurrence of debris flow, analysis of standard rainfall for debris flow occurrence was conducted using Yano method, the result of which is presented on Figure 2 . As shown on the figure, $R$ is working rainfall $(\mathrm{mm})$ and $R$ is maximum rainfall intensity $(\mathrm{mm} / \mathrm{hr})$. Equation $\mathrm{R} h=51-$ 0.085 is the resulted standard rainfall, that is the straight line separating the plots of 
occurrence rainfall and non occurrence one. The plots located on the lower left of the line is supposed to be non occurrence rainfall and the other plots located on the upper right of the line are supposed occurrence rainfall that is able to trigger the occurrence of debris flow. The standard rainfall shown in Figure 2 was established based on rainfall data of Lengkese station $(1,000 \mathrm{~m})$ which is closest to the Bawakaraeng caldera, from December 2005 to February 2008. By comparing the number of plots of non occurrence rainfall which is located on the lower left of standard rainfall line $(K n c)$ with the total number of plots of non occurrence rainfall $(K n)$, the degree of conformity $(S c)$ was $68 \%$. It means that the accuracy of the standard rainfall for debris flow in the Upper Jeneberang River is still low. It is due to the limited data used in the analysis, so it needs to update through collecting and analyzing the short duration rainfall data around the caldera. Figure 2 also shows that rainfall intensity of $40 \mathrm{~mm}$ with relatively short duration has ability to trigger debris flow.

The case occurred in February 16, 2007 that caused Daraha Bridge newly built flashed away. The small intensity with long duration was also able to trigger debris flow. The case occurred in Desember 2007 that was able to destroy the newly constructed check dam No. 7-2 in Manimbahoi village. By plotting the real time data of rainfall in Lengkese station on the graph shown on Figure 2, debris flow in the Upper Jeneberang River can be judged whether it will occur or not, then the result of judgment should be informed to the posts in the downstream through radio and continued to the inhabitants by sirens and/or kentongans. In order to update the standard rainfall, collection of short duration rainfall ( $d$ " 10 minutes interval) has been commenced in the end of Feb-

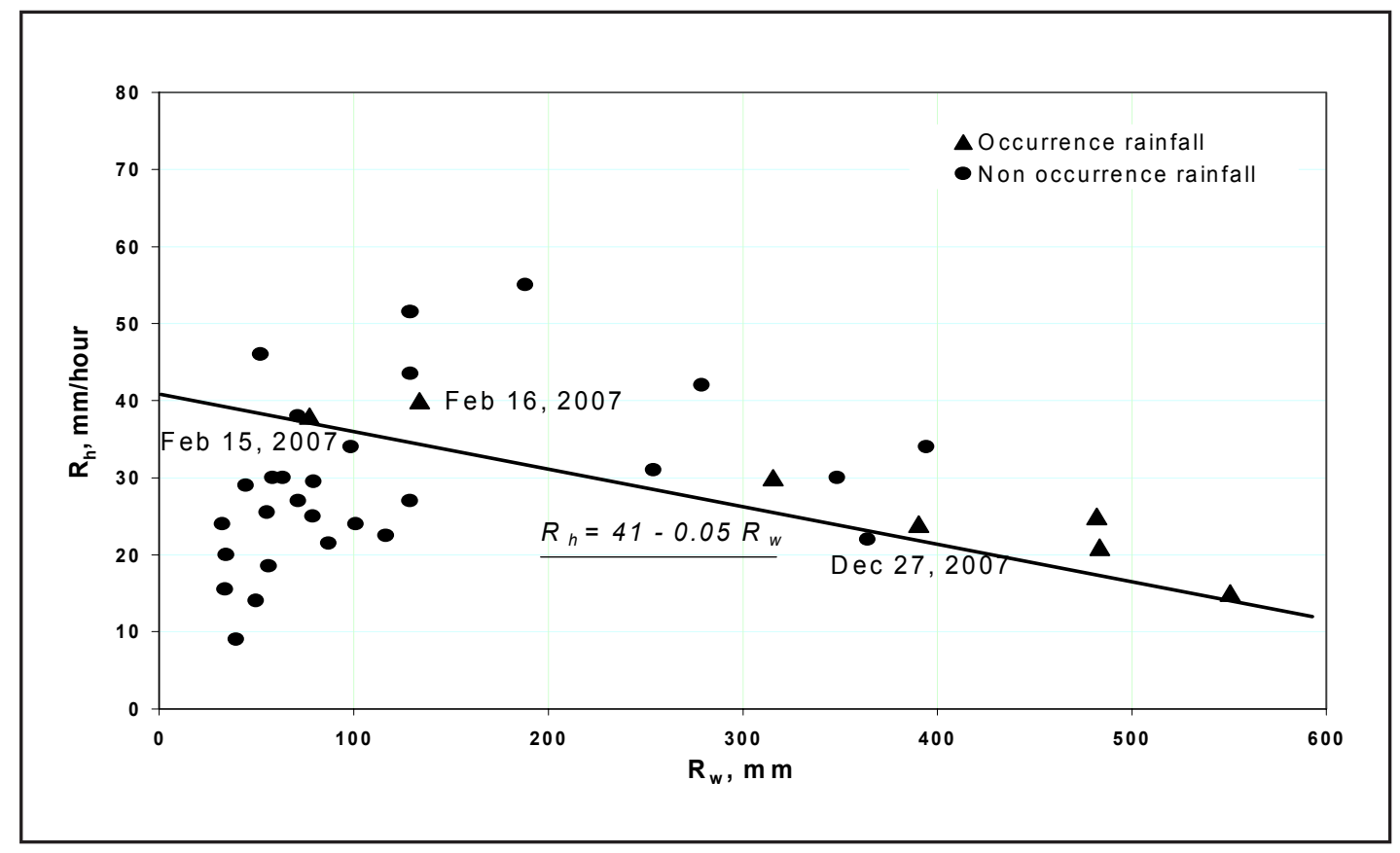

Source: result of analysis.

Figure 2. Standard rainfall for debris flow in the Upper Jeneberang River. 


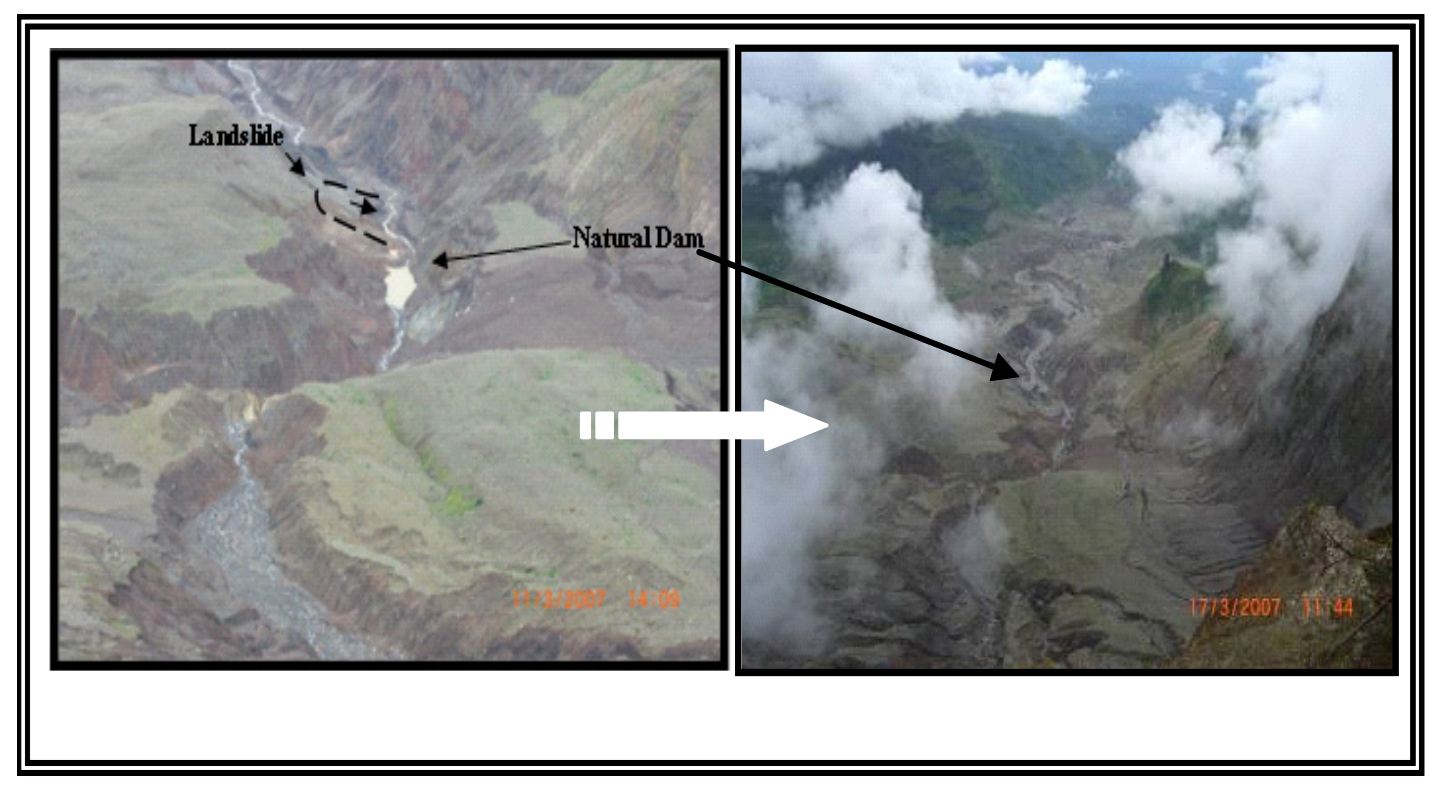

Figure 3. Formation of natural dam in the Upper Jeneberang River,

(Yachiyo Engineering Co, 2008).

ruary 2008 by installing data logger in Lengkese, Panaikang and Majannang.

\section{The Phenomena of natural dam and bank collapses.}

Besides rainfall as a governing variable to trigger debris flow, the formation of natural dam due to the collapse of river bank should also be taken into account. Figure 3 shows an example of natural dam formation in Bawakaraeng Caldera. When the collapse material buries the river course and then flashes away a dangerous debris flow will occur. The phenomena very often exist in the area of Bawakaraeng caldera and caused debris flow even on the non rainy days.

The same phenomena have occurred in Mt. Kelud, East java on July 23, 1998, killing 8 persons, 1 person injured, $54.6 \mathrm{Ha}$ paddy field damaged, and 2 dams were damaged. (Rudy D Hadisusanto, A.D Sumpena, 1998); the explosion of Mt St. Helens, USA in 1980 had formed 2 new lakes that was potentially flashed away and threatened the safety of inhabitant (Dallas Childers, Philip J. Carpenter, 1985). The explosion of St. Helens also killed 57 persons (Tadahiro Matsushita, 1999).

\section{Hazard Area of Debris Flow}

Topographically the hazard area of debris flow in Jeneberang River exists along the river course and river terraces. Daraha Bridge which is located on the elevation of $700 \mathrm{~m}$ above mean sea level is a changing point of river bed slope. Upstream of Daraha Bridge has narrow river course and the height of the bank is greater than $80 \mathrm{~m}$ and river bed slope is $8.3 \%$ in average. Since the gigantic collapse in 2004, the bridge has been three times swept by debris flow. This section is very dangerous since the slope of the river bed is still great and at a point of breaking slope from $8.3 \%$ to $4.0 \%$. The velocity of debris flow is about $10 \mathrm{~m} / \mathrm{s}$ and the arrival time of debris flow is less than 
5 minutes. A suspension bridge for pedestrian and motorcycle has been completely built. Construction of double function check dam located not far from the suspension bridge is now about to start. Besides as sediment control, the check dam has also function as a bridge. For precaution, it still needs warning system for peoples who are traveling across the bridge. Immediately downstream of the point is the spreading area of deposit with the river bed slope of $4 \%$. Figure 4 shows the longitudinal section of Jeneberang River.

The inhabitant along the river is mostly farmers, and the most of their paddy field are located on the lower terraces where they spend most of the time to cultivate. In the downstream of Daraha Bridge to Bulo village, Tanete and Limbua the inhabitant mostly lives on the higher location that is safe from debris flow. The river terraces generally consist of farmland where most of the inhabitants rely their live on them, so it needs warning and evacuation which will inform the possibility of debris flow outbreak. The typical land use along the Jeneberang River can be generalized as shown in Figure 5. In Bulo, it is found that large boulders spread over relatively wide area on the right terrace tells that in the past, debris flow had overtopped the terrace in this area, so it should be designated as dangerous area against debris flow.

Borongsapiria village located on the right bank, just upstream of the confluence point between Malino and Jeneberang rivers where Malino Bridge is located, the height of Malino Road is only 3 meters above river bed. Flood marks found on the flood plain show that highest water level of the past debris flow in the reach was 1.7 $\mathrm{m}$ from the river bed.

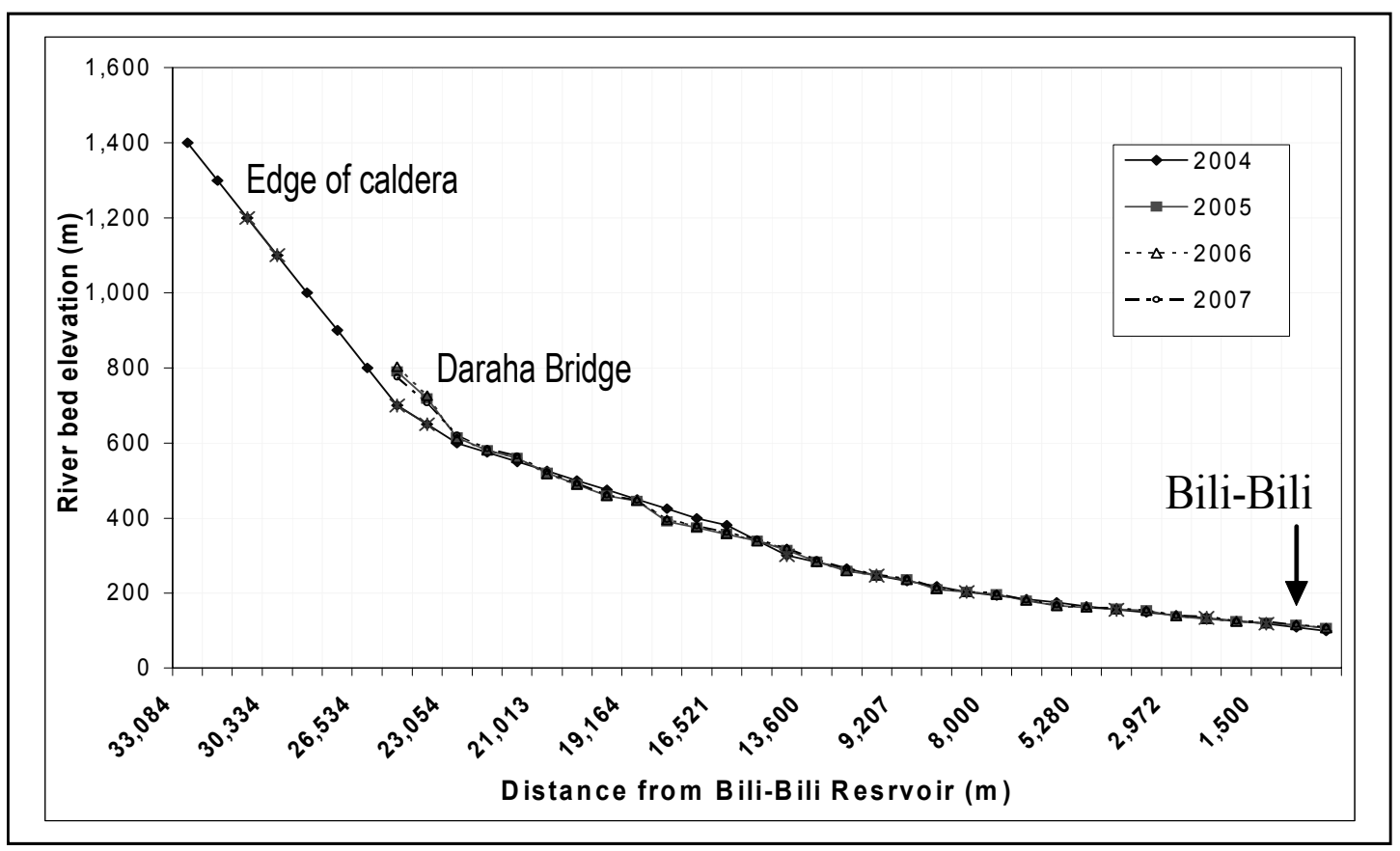

Source: plotted from secondary data.

Figure 4. Longitudinal section of Jeneberang River. 
Safe area 2,

Safe area 2,

villages, road

villages, road

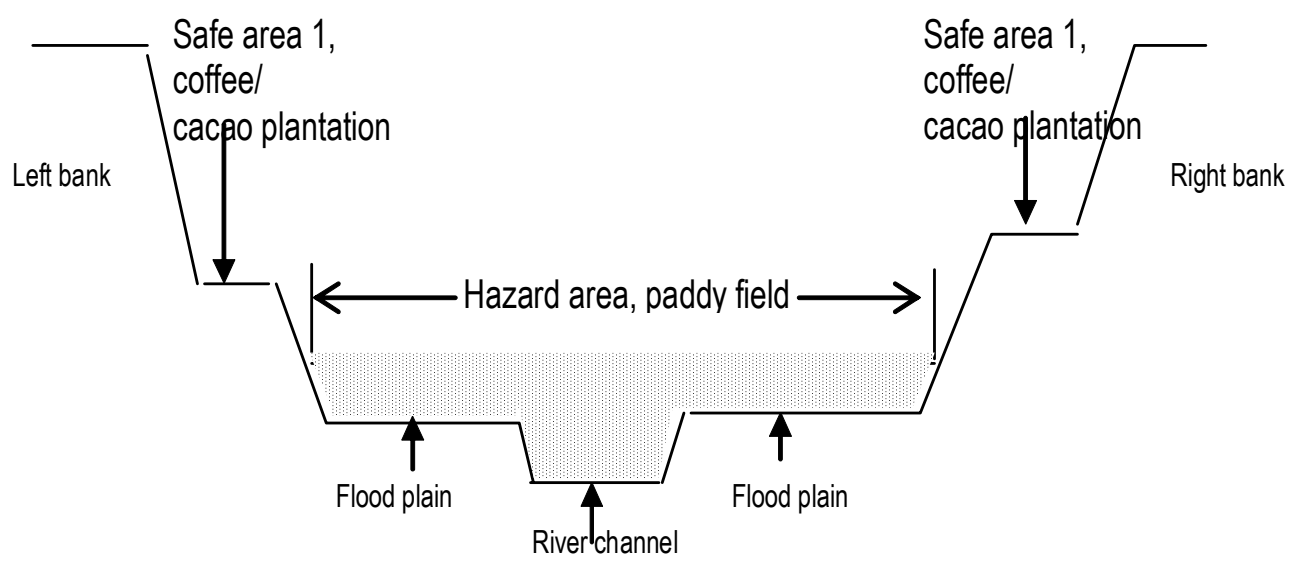

Figure 5. Typical land use along cross section in Jeneberang River

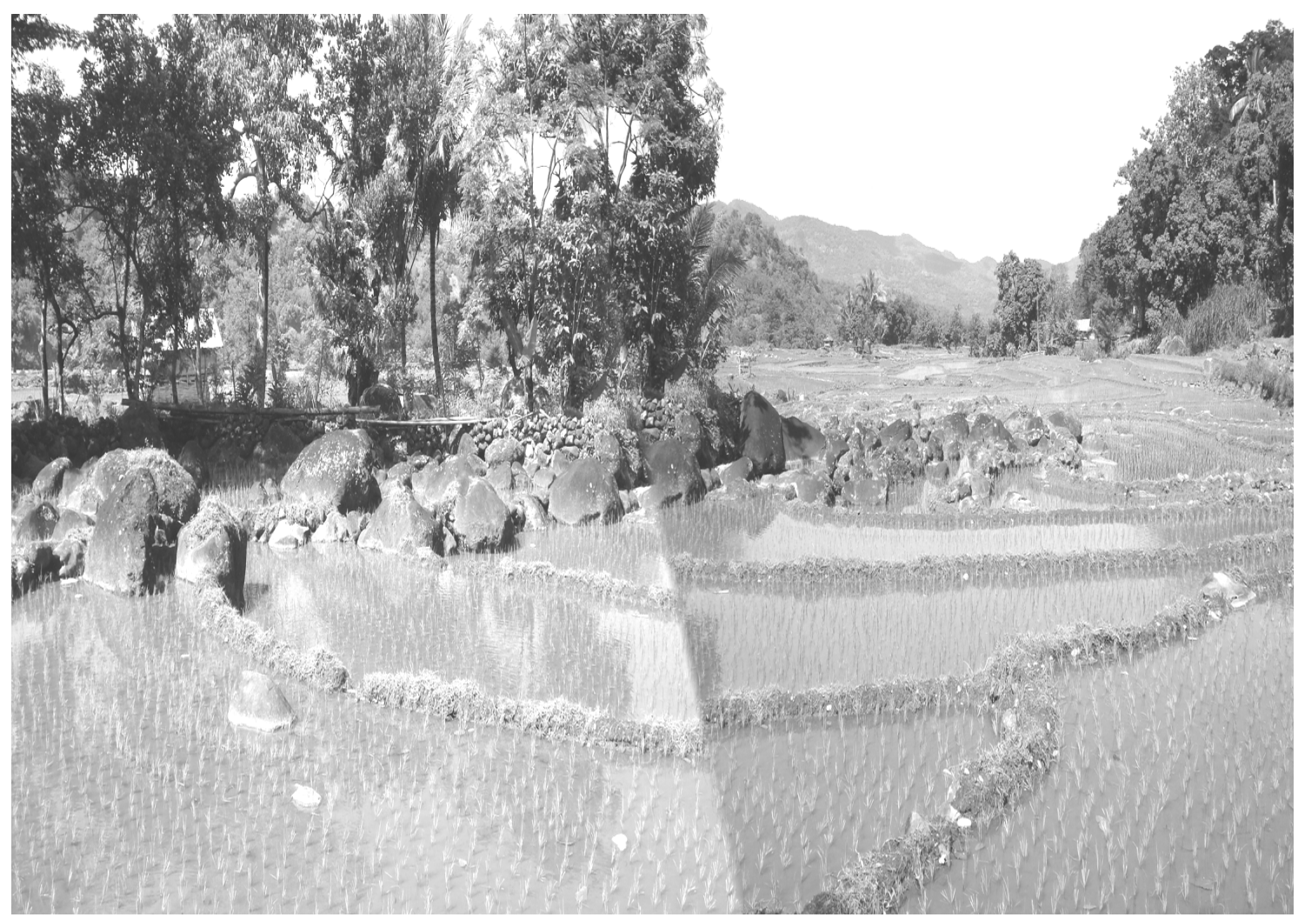

Figure. 6. Spread of boulders over flood plain due to past disaster in Bulo (on the background is Jeneberang River). 


\section{Arrival time of debris flow}

Anticipating the preparedness against debris flow outbreak, the arrival time of debris flow to reach the disaster prone area was computed. Table 1 shows the computed arrival time of debris flow from Parangkeke in the most upstream village to Borongsafiria located just at the confluence point of Malino river and Jeneberang River, which can be generalized into three groups: (1) Parangkeke Bontote'ne (near Daraha Bridge) has arrival time of less than or equals to 8 minutes. (2) Likulambua - Gantung/Bulokarisa has arrival time of 10-15.5 minutes and (3) Bulo - Tanete 24 - 30 minute and (4) Limbua - Borongsafiria $70-85$ minutes.

The value should be compared with the total time needed to propagate the information of warning and the process of evacuation.

\section{Evacuation place and route.}

The existing evacuation roads in the villages along Jeneberang River form the confluence point of Malino River to Jeneberang River are mostly their daily access road to cultivate their farmlands, and the evacuation places are their own home, because their livelihood are farmers so the term escape route is more appropriate than evacuation route. The escape routes generally consist of path on sloping ground with a slope of more than $52.4 \%$, on the coffee or cacao plantations and rice field with relatively gentle slope. The distance from river course to the safety area-I is between $100-1700 \mathrm{~m}$ and travel time by walking is from 2- 30 minutes. The inhabitants have also hamlets on their farmlands in which during peak season they often stay there up to 10 days (CTIE, et al, 2006). In order to solve such a condition, their preparedness against the danger of debris flow

Table 1. Arrival time of debris flow, warning and evacuation time, evacuation road and its condition in Upper Jeneberang River.

\begin{tabular}{|c|c|c|c|c|c|c|c|c|c|}
\hline No. & Location & $\begin{array}{c}\text { Distance } \\
\text { form } \\
\text { reference } \\
\text { point (m) }\end{array}$ & $\begin{array}{l}\text { Distance from } \\
\text { hazard area to } \\
\text { safety } 1(\mathrm{~m})\end{array}$ & \begin{tabular}{|c|} 
Total time of \\
warning and \\
evacuation \\
processes(minute)
\end{tabular} & $\begin{array}{c}\text { Arrival time } \\
\text { of debris } \\
\text { flow (minute) }\end{array}$ & $\begin{array}{c}\text { Spare } \\
\text { time } \\
\text { (minut } \\
\text { e) }\end{array}$ & $\begin{array}{c}\text { Condition of } \\
\text { evacuation road, } \\
\text { slope }\end{array}$ & $\begin{array}{c}\text { Activity of inhabitants } \\
\text { in hazard area }\end{array}$ & $\begin{array}{l}\text { Chance of } \\
\text { evacuation }\end{array}$ \\
\hline (1) & (2) & (4) & (5) & $(10)$ & (12) & $(13)$ & (14) & (15) & (17) \\
\hline 1 & Parangkeke & 0.00 & 1,700 & 30.33 & 0.0 & $(30.33)$ & Path, steep & Farming, cultivating & No chance \\
\hline 2 & Bangkeng Sisang & 405.00 & 1,700 & 30.33 & 0.7 & $(29.66)$ & Path, steep & Farming, cultivating & No chance \\
\hline 3 & Tobanda & 690.00 & 317 & 2.33 & 1.1 & $(1.19)$ & Path, steep & Farming, cultivating & No chance \\
\hline 4 & Janna & 923.00 & 317 & 2.33 & 1.5 & $(0.81)$ & Path, steep & Farming, cultivating & No chance \\
\hline 5 & Batumenteng & $1,793.00$ & 274 & 2.33 & 3.0 & 0.63 & Path, steep & Farming, cultivating & Limited \\
\hline 6 & Bontote'ne & $2,186.00$ & 116 & 2.33 & 8.0 & 5.62 & Path, steep & $\begin{array}{l}\text { Farming, cultivating, } \\
\text { crossing river }\end{array}$ & Sufficient \\
\hline 7 & Putepala & $3,321.00$ & 292 & 4.33 & 12.1 & 7.75 & Path, steep & Farming, cultivating & Sufficient \\
\hline 8 & Liku Lambua & $3,765.00$ & 191 & 4.33 & 13.7 & 9.36 & Path, steep & Cultivating & Sufficient \\
\hline 9 & Gamisang & $4,273.00$ & 300 & 3.33 & 15.5 & 12.21 & Path, steep & Farming, cultivating & Sufficient \\
\hline 10 & Bulo & $6,693.00$ & 357 & 3.33 & 24.3 & 21.01 & Conduit, mild & Farming, cultivating & Sufficient \\
\hline 11 & Puncode/Jonjo & $7,012.00$ & 300 & 3.33 & 25.5 & 22.17 & Path, steep & $\begin{array}{l}\text { Sand mining, } \\
\text { cultivating \& trading }\end{array}$ & Sufficient \\
\hline 12 & Tanete & $8,103.00$ & 670 & 6.33 & 29.5 & 23.14 & Village road, mild & Farming, cultivating & Sufficient \\
\hline 13 & Limbua & $10,844.00$ & 165 & 3.33 & 70.5 & 67.15 & Village road, mild & Farming, cultivating & More than sufficient \\
\hline 14 & Borong Sapiria & $13,070.00$ & 109 & 3.33 & 85.0 & 81.62 & Village road, mild & Farming, cultivating & More than sufficient \\
\hline 15 & Apokang/Pate'ne & $13,144.00$ & 81 & 2.33 & 85.4 & 83.10 & Village road, mild & Sand mining, trading & More than sufficient \\
\hline
\end{tabular}

Source: Result of calculation 
should be improved by periodic socialization and drill. The community based warning system using traditional tools is very relevant.

The plantation of coffee and cacao are generally located relatively on the higher places than the river course and supposed to be safety area-1. However, their houses are located on the elevated land far from river course are designated as safety area-2, except part of Bulo area, Tanete, Limbua and Borongsafiria are located in the hazard area, even not far from sand pocket 4 there is houses located only three meters from river bed. An effort to improve the escape routes has been conducted by Sabo Community of Jeneberang River by making paving block. The budget came from the grass root program - a technical assistance by the Government of Japan - where each community got a budget for paving block of $100 \mathrm{~m}$ length and $1 \mathrm{~m}$ width. However, the improved escape routes are mostly in the zone of safety area-2, near Monitoring Post. It might be due to the lack of guidance to the community. In order to smoothen the evacuation activity, the paving block should be constructed along the escape route.

\section{The effectiveness of warning system}

Several months after occurrence of gigantic collapse of Mt. Bawakaraeng caldera wall, eight monitoring post were established along Jeneberang River from Panaikang on the upstream to Borongsafiria in the downstream. The monitoring posts are operated by Sabo Community Forum in that covers the districts of Tingimoncong and Parigi, the Regency of Gowa. The posts was equipped with radio transceiver, guided by Non Govermental Organization "WAKIL" in Malino town. The posts have duty to monitor the weather and river course condi- tion and propagate the information from the main post in the upstream to the other post in the downstream area. The transfer of information from the monitoring posts to the inhabitants were done by using kentongan. It needs 10 seconds to propagate the information through radio transceiver and $10 \mathrm{sec}-$ onds through kentongan so the total required time to propagate information is 20 seconds. In the research, manual siren that does not need electricity was introduced to the inhabitants and they accepted the use of sirens for early warning tools. In order to evaluate the effectiveness of siren and kentongan, a series of sound tests were conducted in 6 monitoring posts. They were Manimbahoi, Putepala, Bulo, Tanete, Limbua and Jonjo. The variable to be measured in the sound test were sound pressure level at an interval of 50 meters until a maximum listenable distance. The background noise around the test site was assumed $55 \mathrm{db}$. The result of sound test in Jeneberang River is summarized on Table 2.

The sufficiently long coverage of sound test in Limbua and Jonjo were affected by the open area. Besides, the valley on the reach is situated in between two hills that gave an echo effect so the sound of kentongan and siren could be heard from sufficiently long distance. In Putepala, the siren directed to the upstream (Daraha Bridge) which is also an open area gave almost same result with Limbua and Jonjo., At the same test site with downstream direction, however, the maximum distance was $160 \mathrm{~m}$ due to the blockage of high river bank. In Bulo and Tanete, the maximum hearable distance of siren and kentongan were little bid lower than Limbua and Jonjo. It can be concluded that siren and kentongan can be applied since they are complementary. 
Table 2. Result of sound test of siren and kentongan di Jeneberang River

\begin{tabular}{|c|l|l|l|l|}
\hline \multirow{2}{*}{ No } & \multirow{2}{*}{$\begin{array}{c}\text { Maximum } \\
\text { distance }(\mathrm{m})\end{array}$} & \multicolumn{1}{|c|}{ Location of sound test } & \multicolumn{2}{|c|}{ Sound pressure level $(\mathrm{db})$} \\
\cline { 4 - 5 } & $100<\mathrm{L} \leq 200$ & $\begin{array}{l}\text { Manimbahoi dan Putepala } \\
\text { (daownstream) }\end{array}$ & $56 ; 57$ & $56 ; 62$ \\
\hline 2 & $200<\mathrm{L} \leq 400$ & Bulo dan Tanete & 56,$5 ; 67,1$ & 58,$4 ; 67,9$ \\
\hline 3 & $400<\mathrm{L} \leq 600$ & $\begin{array}{l}\text { Limbua, Jonjo dan Putepala } \\
\text { upstream. }\end{array}$ & 71,$1 ; 57,5 ; 56$ & 71,$3 ; 55 ; 56$ \\
\hline
\end{tabular}

Source: Result of analysis

\section{Required time for evacuation or escape.}

The required time for escape to safety area-1 is strongly influenced by the condition of the escape route. Field measurement of escape time shows that the route which mostly consists of path road with the slope of greater than $52.4 \%$, and the distance between $100 \mathrm{~m}$ to $1700 \mathrm{~m}$ takes 2 to $30 \mathrm{~min}$ utes. The total time required to transfer a warning message from the main post to the inhabitants in the hazard are shown on Table 1. Comparing the total time with the arrival time of debris flow, it can be concluded that from 15 escape routes observed, 4 (four) locations are no chance to escape when debris flow occurred, they are Parangkeke, Tobanda, Janna and Bangkeng Sisang; One location (Batu Menteng) has limited chance to escape; 7 (seven) location have enough chance to escape. They are Bontote'ne, Putepala, Likulambua, Gamisang, Bulo, Puncode/Jonjo and Tanete. Three locations have much time to escape when debris flow occur, they are Borong Safiria and Apokang/ Pate'ne. The different chance of escape is due to the different river bed gradient, river width, distance of safety area-1 from the river course and condition of the escape route.
Warning system is a non structural measure to mitigate the hazard risk against debris flow outbreak. With regard to the improvement of people awareness to their environment, the community based mitigation of hazard has been developed. It is hoped that the community take a part actively in the hazard mitigation since they know more what is going on in their environment. A Sociologist said that every human being knows their own world better than any other outsider - including the expert who makes policy- (P.L. Berger, 1974).

Three months after Gigantic collapse of Mt. Bawakaraeng, the Sabo Community Forum was established by the local inhabitants in Malino town, under the guidance of the Local Government of Gowa Regency, Ministry of Public Works and the Japan International Cooperation Agency (JICA). The organization is purposed to prevent from further damage due to debris flow, recovery from the condition of disaster and regional development. So far, there are 23 groups of Sabo Community spread along Jeneberang River, from Lengkese to the confluence point of Malino River with Jeneberang River, the total number of which are 741 persons. 
At the early stage of its establishment, the activity of the community are: (1) monitoring the caldera wall, rainfall and debris flow; (2) transfer the information of early warning to the inhabitants in the downstream area; (3) workshop, meeting and campaign through involving the inhabitants; (4) training of facilitator; (5) training of making paving block using debris flow deposit; and participate in making the emergency bridge or Daraha. There are eight monitoring posts constructed by Sabo Community. In the rainy season each post is guarded by two volunteers every day to monitor debris flow, in the dry season the posts are guarded by the head of the group of Sabo Community and equipped with handy talky (CTIE, et al, 2006).

With refer to the transfer of early warning against debris flow, a broadcasting station donated by the Government of Japan was established in Malino town. At the same time, 1,000 units of transistor radio were also donated and distributed to all member of Sabo Community in 23 locations along Jeneberang River. It was expected that the transistor radio will be used to monitor the broadcasting of warning message in Malino and other related information. However, the result of interview to the member of the community and a field observation shows that the broadcast was only one months on air, and could not be well monitored by the community and the TV broadcast was disturbed, so then the broadcast stopped. It can be said that the broadcasting station did not contribute to the early warning system in Jeneberang River. The result of interview also shows that from five initial activities of Sabo Community, two activities remain going on, they are activity no 1 and no 2 .
Up to 2007 the early warning system is based on the rainfall condition in Lengkese and Panaikang and visual observation on the eight monitoring posts and transferred to the inhabitants in the hazard area. According to daily report of Sabo Community Forum in Malino, the flow of information only occurred between monitoring post within the community. No communication from the community to the SATLAK PBP in the activity of early warning system. In the community based warning system, it is hoped that the community actively participate in the activity. In the existing system, there is no rainfall standard yet for debris flow warning.

\section{CONLUSSION}

1) Debris flow occurrence in Jeneberang River - where the material was supplied by the collapse of Bawakaraeng caldera is governed by short duration of high rainfall intensity, long duration of medium and low rainfall and it has been tentatively formulated in the form of standard rainfall that can be applied as warning criteria.

2) The hazard areas are mostly located along the lower terraces of the river where the inhabitants work and live temporarily to cultivate their farmlands, they made temporariy houses to live for several days during peak season and living together with disaster. On the upper reaches above elevation $700 \mathrm{~m}$ (upper stream of Daraha Bridge), people who stay on the river course are mostly no chance to escape when debris flow occur; on the middle reaches from Daraha Bridge to Tanete they have enough time to escape and lower than Tanete they have much time to escape. 
3) The community based warning system has been commenced through establish-ing Sabo Community Forum which actively participates to monitor the rain-fall and field condition, sending infor-mation the the inhabitant by using radio transceiver combined with manual siren and kentongan which have been examined their sound strength and maximum distance.

\section{RECOMMENDATION}

1) Necessity to continuously monitor short duration rainfall at the key stations, updating the standard rainfall using those data and propagating the warning to the inhabitants by using transceivers, manual sirens and kentongans to the inhabitants and construct mew monitoring post in Lengkese to inform the rainfall condition.

2) Maintaining the established community based warning system in Jeneberang River through maintenance of equipment and periodic evacuation drill to check the preparedness on the system.

3) Synergizing the local Government of Gowa and other stakeholders to the
Sabo Community Forum in the activity of early warning system

\section{ACKNOWLEDGEMENT}

The Writers express their gratitude to the Head of Agency for Research and Development, and to the Head of Research Centre For Water Resources Development, and to the Head of Experimental Station for Sabo for their support and accommodate the budget for the research. A special thank is expressed to Mr. Bambang Sigit, the head of Jeneberang Project Office, Mr. Wakito and Mr. Haeruddin for their support and input to the research. The Writers also express their thankfulness to CTIE Co, Yachiyo Engineering Co., Hazama-Brantas Jo, and Hazama - Wijaya Karya JO for their support the required data. Thank is also given to the Head of Gowa Regency, Head of Tinggimoncong and Parigi Districts for their co-operation in the research activity. Special gratitude is expressed to Sabo Community, the member of Wahana Kesehatan dan Lingkungan (WAKIL) for their help in the survey activity and finally to all parties for their help in the research.

\section{REFERENCES}

Berger P.L., 1974, as in Gutomo, Drs, M. Hum, 2007, Community Based Development dalam Pengelolaan Daerah Rawan Bencana Alam Sedimen, Seminar Nasional Pengelolaan Daerah Bencana Alam Sedimen Secarfa Terpadu, Yogyakarta, 5-6 Desember 2007

CTI Engineering International Co., Ltd in Association with PT Indra Karya, PT Indah Karya, PT Connusa Engineering, PT Puri Fadjar Mandiri, PT Wiranta Bhuana Karya, 2006, Report on Urgent Survey for Consulting Engineering Services of Bawakaraeng Urgent Sediment Control Project, The Most Urgent Components, The Government of the Republic of Indonesia, Ministry of Public Works, Directorate General of Water Resources, March, 2006.

Dallas Childers, Philip J. Carpenter, 1985, A Warning System for Hazards Resulting from Breaches of Lake Blockage, Mount St. Helens, Washington, Proceedings of the International 
Symposium on Erosion, Debris Flow and Disasater Prevention. Tsukuba, Japan, p. 493498.

Hazama - Brantas J.O - Government of the Republic of Indonesia, Ministry of Public Works, Dir. Gen. of Water Resources Development, 2007, Flood Report on February 2007, Bawakaraeng Urgent Sediment Control Project, Most Urgent Component Contract Package No. 2-1 (IP-524)

Rudy D.Hadisantono, and A.D. Sumpena, 1998, Tragedy of July 23, 1998 at Kelud Volcano, East Java, Proceedings of Symposium on Japan-Indonesia IDNDR Project, Volcanology, Techtonics, Flood and Sediment Hazards, organized by Disaster Prevention Research Institute, Koto University, Volcanological Survey of Indonesia, Research Institute for Water Resources Develoment, supported by Ministry of Education, Science, Sport and Culture, Japan, 1998, Bandung, Indonesia.

Suratman Worosuprojo. 2007. "Analisis Spasial Ekologikal Sumberdaya Lahan di Provinsi Daerah Istimewa Yogyakarta”. Forum Geografi, Vol. 21, No. 2, Desember 2007. Hlm. 95-103.

Sutikno Hardjosuwarno, Bambang Sukatja, Haryanto, Koji NAKANISHI, 2005, Warning System Against Mudflow Disaster in Gendol River, Mt. Merapi Area, Proceedings of the International Conference on Integrated Sediment Related Disaster, August 3-5, 2005.

Tadahiro Matsushita, 1999, MESSAGES FOR THE $21^{\text {ST }}$ CENTURY, Sabo Works and its Acbievements, Sabo Publicity Center, No. 3 Hasegawa Building, 13-1 Shinbasi 6-chome, Minato-ku, Tokyo 105-0004.

Yano, K, Senoo, K, 1985, How to set Standard Rainfalls for Debris Flow Warning and Evacuation, Proceedings of the International Symposium on Erosion, Debris Flow and Disasater Prevention. Tsukuba, Japan, p. 451-453.

Yachiyo Engineering CO. Ltd and Associates , 2008, Urgent Disaster Reduction Project for Mt.Bawakaraeng, Departemen Pekerjaan Umum, Direktorat Jenderal Sumber Daya Air, Balai Besar Wilayah Sungai Pompengan-Jeneberang and, 31 Maret 2008. 